\title{
EKSTRAKSI WET RENDERING MINYAK IKAN LAYANG (Decapterus macarellus) DENGAN SUHU RENDAH
}

\author{
Sugeng H. Suseno, Kamini, Desi Listiana* \\ Departemen Teknologi Hasil Perairan, Fakultas Perikanan dan Ilmu Kelautan, Institut Pertanian Bogor \\ Institut Pertanian Bogor, Kampus IPB Darmaga, Jalan Agatis, Bogor 16680 Jawa Barat \\ Telepon (0251) 8622909-8622906, Faks. (0251) 8622915 \\ Diterima: 24 September 2020/Disetujui: 10 Desember 2020 \\ ^Korespondensi: sug_thp@yahoo.com
}

Cara sitasi: Suseno SH, Kamini, Listiana D. 2020. Ekstraksi wet rendering minyak ikan layang (Decapterus macarellus) dengan suhu rendah. Jurnal Pengolahan Hasil Perikanan Indonesia. 23(3): 495-502.

\begin{abstract}
ABSTRAK
Ikan layang (Decapterus macarellus) merupakan ikan pelagis kecil yang pemanfaatannya masih terbatas pada pengolahan ikan asin, ikan pindang, dan ikan asap dengan nilai tambah yang rendah. Kandungan asam lemak omega-3 ikan layang yang cukup tinggi berpotensi sebagai bahan baku pengolahan minyak ikan. Tujuan penelitian ini adalah menentukan karakteristik mutu minyak ikan layang terbaik yang mengacu pada International Fish Oil Standards (IFOS). Ekstraksi minyak ikan layang dilakukan dengan metode wet rendering perlakuan suhu 40,50, dan $60{ }^{\circ} \mathrm{C}$ selama 30 menit, dilanjutkan dengan analisis karakteristik mutu untuk menentukan suhu ekstraksi terbaik. Karakteristik mutu minyak ikan layang terbaik diperoleh dari ekstraksi perlakuan suhu $60{ }^{\circ} \mathrm{C}$ dengan nilai PV, p-AV, dan TOTOX yang telah memenuhi persyaratan IFOS dengan rendemen sebesar $0,9 \pm 0,04 \%$.
\end{abstract}

Kata kunci: Decapterus macarellus, ekstraksi, IFOS, kualitas minyak, suhu

\section{Wet Rendering Extraction of Mackerel Scad (Decapterus macarellus) Oil by Low Temperature}

\section{ABSTRACT}

Mackerel scad (Decapterus macarellus) is a small pelagic fish which their utilization is still limited to salted fish, pindang fish, and smoked fish with low added value. The high content of omega-3 fatty acids makes the fish a potential source of fish oil. The purpose of this study was to determine the quality of the fish oil from mackerel scad and compare to the International Fish Oil Standards (IFOS). The extraction of mackerel scad oil was carried out by wet rendering treatment at temperatures of 40,50 , and $60{ }^{\circ} \mathrm{C}$ for 30 minutes, followed by analysis of quality characteristics to determine the best extraction temperature. The best quality characteristics of mackerel scad oil were obtained from the extraction at $60{ }^{\circ} \mathrm{C}$ with $\mathrm{PV}, \mathrm{p}-\mathrm{AV}$, and TOTOX values that met the requirements of IFOS and a yield of $0.9 \pm 0.04 \%$.

Keywords: Decapterus macarellus, extraction, IFOS, oil quality, temperature

\section{PENDAHULUAN}

Ikan layang (Decapterus macarellus) merupakan ikan pelagis kecil yang terdapat di perairan Indonesia dan mendominasi WPPNRI 713. Rata-rata produksi di WPPNRI 713 tahun 2005-2015 mencapai 50.649 ton per tahun (DJPT 2016). Data hasil tangkapan ikan layang biru tahun 20132018 di PPP Tumumpa yaitu 90\% dari total hasil tangkapan komoditas ikan pelagis kecil (KKP 2019). Tingkat produksi ikan layang (Decapterus sp.) di atas rata-rata terjadi pada bulan April hingga Oktober (Hamka dan Rais 2016). Ikan layang dengan tingkat produksi yang tinggi dimanfaatkan sebagai bahan pangan. Pemanfaatan ikan layang masih terbatas sebagai bahan baku ikan asin (Imbir et al. 2015), ikan asap (Hadinoto dan Kolanus 2017), dan tepung ikan (Deslianti et al. 2016). Kandungan gizi yang cukup tinggi pada ikan layang salah satunya adalah asam lemak omega-3 (EPA dan DHA). Metillo dan Eya (2014) melaporkan bahwa ikan layang mengandung omega-3 sebesar 
16,23\% dengan kadar EPA sebesar 2,50\% dan DHA sebesar 12,40\%. Kandungan asam lemak ini memiliki potensi untuk dimanfaatkan sebagai bahan baku pengolahan minyak ikan.

Minyak ikan merupakan suatu komponen lemak yang terdapat dalam jaringan tubuh ikan dan dilakukan proses ekstraksi dalam bentuk minyak (Estiasih 2009). Pramestia et al. (2015) menyatakan bahwa minyak ikan merupakan sumber asam lemak yang tinggi omega-3. Kandungan omega-3 dalam minyak ikan terutama eicosapentaenoic acid (EPA) dan docosahexaenoic acid (DHA) memiliki fungsi fisiologi untuk kesehatan misalnya menurunkan risiko penyakit kardiovaskular (He 2009). International Fish Oil Standards (IFOS) (2014) menetapkan minyak ikan yang berkualitas yaitu memiliki bilangan asam lemak bebas $\leq 1,50 \%$, nilai peroksida $(\mathrm{PV}) \leq 5,00 \mathrm{mEq} / \mathrm{kg}$, nilai anisidin $\leq 20,00 \mathrm{mEq} / \mathrm{kg}$, dan total oksidasi $\leq 19,50$ $\mathrm{mEq} / \mathrm{kg}$. Penggunaan suhu tinggi $\left(>70{ }^{\circ} \mathrm{C}\right)$ menjadi masalah utama pada produksi minyak ikan karena dapat menurunkan kualitas minyak yang tidak stabil terhadap panas (Carvajal et al. 2014).

Ekstraksi dengan suhu rendah menjadi salah satu solusi untuk memperbaiki kualitas minyak ikan yang dihasilkan. Suhu rendah secara relatif adalah ukuran suhu kurang dari atau sama dengan $158^{\circ} \mathrm{F}$ atau $70{ }^{\circ} \mathrm{C}$ (Richard dan Brien, 2008). Ekstraksi minyak ikan dilakukan dengan metode wet rendering menggunakan akuades sebagai carrier. Akuades yang digunakan sebagai carrier memiliki keunggulan karena lebih ekonomis dan relatif aman (Estiasih 2009). Ekstraksi minyak ikan yang telah dilakukan di antaranya dari hasil samping pengolahan patin siam menggunakan dry rendering (Kamini et al. 2016), hati ikan cucut dengan metode dry rendering (Rozi et al. 2019), hasil samping industri filet patin (Suseno et al. 2020). Penelitian ekstraksi minyak ikan layang telah dilakukan oleh Luthfiah et al. (2014) dengan metode steam and press suhu $90{ }^{\circ} \mathrm{C}$ selama 15 menit, namun masih menghasilkan minyak ikan dengan bilangan peroksida dan total oksidasi yang belum memenuhi IFOS. Penelitian ini ditujukan untuk menentukan kualitas minyak ikan yang baik menggunakan metode wet rendering suhu rendahaksi terhadap kualitas minyak ikan yang dhasilkan. Ekstraksi minyak ikan layang dilakukan dengan memanfaatkan seluruh bagian tubuh ikan (whole) yang diharapkan dapat menghasilkan kualitas minyak ikan sesuai dengan IFOS. Penelitian ini bertujuan menentukan karakteristik mutu minyak ikan layang terbaik dengan perlakuan suhu ekstraksi $40,50,60^{\circ} \mathrm{C}$ yang membandingkan dengan IFOS.

\section{BAHAN DAN METODE Bahan dan Alat}

Bahan utama yang digunakan pada penelitian ini adalah ikan layang yang diperoleh dalam kondisi segar dari PPS Nizam Zachman, Muara Baru, Jakarta, etanol (Merck 107553), indikator fenolftalein (Merck 107233), kalium iodida (Merck 105043), kalium hidroksida (Merck), indikator pati (Merck), asam asetat glasial (Marck 100063), sodium tiosulfat (Merck 106516), isooktan (Merck 104727), metanol (Merck), $\mathrm{NaOH}$ (Merck 106498), standar Supelco ${ }^{\mathrm{TM}} 37$ component fatty acid methyl esters (FAME) Mix dan isooktan. Peralatan yang digunakan dalam penelitian yaitu waterbath (F-ScientificLabs, Indonesia), blender (Miyako BL-152 PF/ AP), buret (Pyrex, Jerman), peralatan gelas (Iwaki), timbangan digital (Chq, Taiwan, 0,01 gram), alumunium foil, kompor listrik (Maspion, Indonesia), termometer (Pyrex, Jerman), spektrofotometer (Shimadzu spektrofotometer UV Pharmaspec 1700), dan kromatografi gas (Shimadzu, Jepang, model GC2010 dengan kolom cyanopropyl methyl sil (capillary column), dimensi kolom $\mathrm{p}=$ $60 \mathrm{~m}, \varnothing=0,25 \mathrm{~mm}, 0,25 \mathrm{~m}$ ketebalan film), sentrifugasi (seri PLC), dan freezer.

\section{Prosedur Penelitian Ekstraksi wet rendering (Wanasundara 1996)}

Penelitian diawali dengan melakukan preparasi sampel ikan layang segar dengan penghalusan menggunakan blender kemudian dilakukan analisis komposisi kimia (AOAC 2005) dan ekstraksi. Proses ekstraksi dilakukan dengan memodifikasi metode Wanasundara (1996). Perlakuan suhu 
ekstraksi yang digunakan mengacu pada Suseno et al. (2014) dengan suhu 40, 50, dan $60{ }^{\circ} \mathrm{C}$. Ikan yang telah dihaluskan pada tahap preparasi sampel selanjutnya ditambahkan akuades (1:1) (w/v). Proses ekstraksi dilakukan pemanasan menggunakan waterbath shaker kecepatan $20 \mathrm{rpm}$ selama 30 menit dengan perlakuan suhu yang berbeda, yaitu 40, 50, dan $60^{\circ} \mathrm{C}$. Setiap perlakuan suhu dilakukan 4 kali pengulangan. Tahap selanjutnya yaitu pemisahan air dan ampas daging dengan penyaringan. Air hasil penyaringan selanjutnya disimpan dalam freezer pada suhu $-18{ }^{\circ} \mathrm{C}$. Ampas daging dilakukan pengepresan sehingga menghasilkan cairan kemudian dipisahkan dari residu dengan sentrifugasi kecepatan $11.200 \times \mathrm{g}$ selama 10 menit pada suhu $4{ }^{\circ} \mathrm{C}$. Filtrat minyak hasil sentrifugasi dipisahkan dengan pipet yang selanjutnya disimpan dalam freezer suhu $-18{ }^{\circ} \mathrm{C}$. Minyak hasil ekstraksi dilakukan analisis karakteristik mutu meliputi nilai asam lemak bebas (SNI 8392-1:2018), bilangan peroksida (SNI 83922:2018), bilangan p-anisidin (IUPAC 1987), dan total oksidasi (AOCS 1997).

\section{Analisis Data}

Pengaruh suhu ekstraksi terhadap karakteristik minyak dianalisis menggunakan Rancangan Acak Lengkap (RAL) dengan percobaan satu faktor yaitu suhu. Faktor suhu terdiri dari 3 taraf yaitu 40,50 , dan $60{ }^{\circ} \mathrm{C}$ dengan 4 kali pengulangan. Pengolahan data dilakukan dengan aplikasi Microsoft Excel 2010 dan perlakuan dianalisis secara statistik dengan analisis ragam (ANOVA) perangkat lunak SPSS 22.0. Parameter yang diamati adalah rendemen, asam lemak bebas, bilangan peroksida, bilangan p-anisidin, dan total oksidasi. Apabila hasil analisis keragaman pada selang kepercayaan 95\% menunjukkan pengaruh nyata, maka dilakukan uji lanjut
Duncan untuk melihat perbedaan dari masing-masing perlakuan.

\section{HASIL DAN PEMBAHASAN Komposisi Kimia}

Seluruh bagian tubuh ikan layang yang telah dipreparasi dalam bentuk pasta dianalisis komposisi kimia. Parameter karakteristik kimiameliputi kadar lemak, air, abu, protein, dan karbohidrat. Komposisi kimia ikan layang disajikan pada Table 1. Kadar lemak ikan layang adalah 1,48 $\pm 0,25 \%$ (Table 1). Hasil ini lebih rendah dari $D$. russelli $0,24 \pm 0,06 \%$ (Nurpratama 2019) dan lebih tinggi dari Decapterus sp. sebesar 1,90\% (Hadinoto dan Kolanus 2017). Perbedaan komposisi kimia pada jenis ikan yang sama dapat dipengaruhi oleh faktor internal dan eksternal, seperti musim, habitat, dan stadium ikan. Penyimpanan lemak pada ikan bervariasi selama periode makanan dan reproduksi. Lemak pada ikan yang mengalami matang gonad banyak terkonsentrasi di bagian gonad (Castell et al. 1972).

\section{Rendemen Minyak Ikan Layang}

Rendemen minyak ikan layang terbesar diperoleh dari perlakuan suhu ekstraksi $60^{\circ} \mathrm{C}$, yaitu sebesar $0,9 \pm 0,04 \%$. Rendemen minyak ikan layang hasil ekstraksi dapat dilihat pada Figure 1. Rendemen minyak ikan layang meningkat seiring dengan bertambahnya suhu ekstraksi. Hasil analisis sidik ragam (varian) menunjukkan bahwa perlakuan suhu ekstraksi berpengaruh nyata $(p \leq 0,05)$ terhadap rendemen minyak ikan layang yang dihasilkan. Uji lanjut Duncan menunjukkan bahwa rendemen pada perlakuan suhu ekstraksi $40{ }^{\circ} \mathrm{C}$ dan $60^{\circ} \mathrm{C}$ berbeda nyata. Hasil ini sesuai dengan penelitian Suseno et al. (2014) yang menunjukkan bahwa ekstraksi wet rendering suhu $40-60{ }^{\circ} \mathrm{C}$ pada jeroan ikan

Table 1 Chemical composition of D. macarellus

\begin{tabular}{lrrr}
\hline \multicolumn{1}{c}{ Parameter } & D. macarellus & Decapterus sp $^{*}$ & D. ruselli* $^{\star *}$ \\
\hline Lipid (\%) & $1.48 \pm 0.25$ & 1.90 & $0.24 \pm 0.02$ \\
Moisture(\%) & $72.62 \pm 0.78$ & 72.50 & $73.01 \pm 0.44$ \\
Ash (\%) & $4.07 \pm 0.37$ & 1.45 & $1.43 \pm 0.06$ \\
Protein (\%) & $16.82 \pm 0.23$ & 26.31 & $22.29 \pm 0.92$ \\
\hline
\end{tabular}

Note: ${ }^{*}=$ Hadinoto and Kolanus (2017); ${ }^{* *}=$ Nurpratama (2019) 


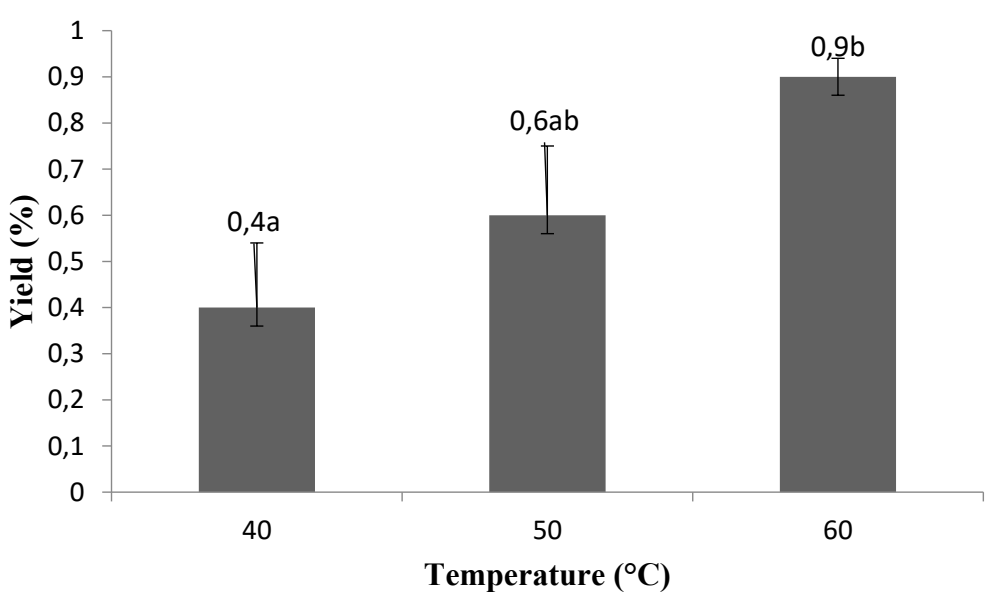

Figure 1 Yield of D. macarellus fish oil.

tembang (Sardinella gibbosa) dan ikan siro (Amblygaster sirm) menghasilkan rendemen minyak yang semakin meningkat seiring dengan meningkatnya suhu. Adeoti dan Hawbolt (2014) menyatakan bahwa suhu pada proses ekstraksi minyak ikan berpengaruh terhadap kerusakan membran sel jaringan lemak, sehingga semakin tinggi suhu ekstraksi maka rendemen minyak yang dihasilkan semakin besar. Hasil penelitian Luthfiah et al. (2014) yaitu minyak ikan layang yang diekstraksi dengan metode steam and press suhu $90{ }^{\circ} \mathrm{C}$ selama 15 menit menghasilkan rendemen sebesar 3,07\%.

\section{Karakteristik Mutu Minyak Ikan Layang}

Minyak hasil ekstraksi wet rendering dianalisis karakteristik mutunya berdasarkan IFOS (2014). Parameter yang dianalisis meliputi asam lemak bebas, bilangan peroksida, bilangan $p$-anisidin, dan bilangan total oksidasi. Karakteristik mutu minyak ikan layang dapat dilihat pada Table 2.

\section{Asam Lemak Bebas}

Asam lemak bebas atau free fatty acid (FFA) merupakan hasil hidrolisis ikatan ester pada trigliserida (Scrimgeour 2005). Peningkatan nilai FFA dapat menurunkan kualitas dan menyebabkan ketengikan pada minyak (Ketaren 2012). Nilai FFA minyak ikan layang tertinggi pada perlakuan suhu ekstraksi $50{ }^{\circ} \mathrm{C}$ sebesar $8,54 \%$ (Table 2). Nilai FFA minyak ikan layang meningkat pada perlakuan suhu ekstraksi $50{ }^{\circ} \mathrm{C}$ dan menurun pada suhu ekstraksi $60{ }^{\circ} \mathrm{C}$ (Table 2). Hasil analisis sidik ragam (varian) menunjukkan bahwa perlakuan suhu ekstraksi berpengaruh nyata $(p \leq 0,05)$ terhadap nilai FFA minyak ikan layang. Uji lanjut Duncan menunjukkan bahwa nilai FFA pada setiap perlakuan suhu berbeda nyata. Suseno et al. (2014) melaporkan bahwa nilai FFA hasil ekstraksi wet rendering perlakuan suhu $40-60{ }^{\circ} \mathrm{C}$ pada jeroan ikan tembang (S. gibbosa) meningkat

Table 2 Quality Characteristics of D. macarellus Fish Oil

\begin{tabular}{|c|c|c|c|c|}
\hline \multirow{2}{*}{ Parameter } & \multicolumn{3}{|c|}{ Temperature } & \multirow{2}{*}{$\begin{array}{c}\text { IFOS } \\
(2014)\end{array}$} \\
\hline & $40^{\circ} \mathrm{C}$ & $50^{\circ} \mathrm{C}$ & $60^{\circ} \mathrm{C}$ & \\
\hline FFA (\%) & $6.19 \pm 0.18^{\mathrm{a}}$ & $8.54 \pm 0.26^{c}$ & $7.32 \pm 0.53^{b}$ & $\leq 1.5$ \\
\hline $\mathrm{PV}(\mathrm{mEq} / \mathrm{kg})$ & $4.02 \pm 0.71^{\mathrm{a}}$ & $4.90 \pm 0.21^{\mathrm{b}}$ & $4.91 \pm 0.48^{\mathrm{b}}$ & $\leq 5.0$ \\
\hline $\mathrm{p}-\mathrm{AV}(\mathrm{mEq} / \mathrm{kg})$ & $3.07 \pm 0.51^{\mathrm{a}}$ & $3.81 \pm 0.47^{\mathrm{b}}$ & $6.69 \pm 0.13^{c}$ & $\leq 20.0$ \\
\hline TOTOX (mEq/kg) & $11.11 \pm 1.93^{\mathrm{a}}$ & $13.61 \pm 0.89^{\mathrm{b}}$ & $16.5 \pm 1.09^{\mathrm{c}}$ & $\leq 19.5$ \\
\hline
\end{tabular}


pada suhu $50{ }^{\circ} \mathrm{C}$ dan menurun pada suhu $60{ }^{\circ} \mathrm{C}$. Hasil ini diduga disebabkan adanya reaksi kesetimbangan, sehingga ikatan ester antara asam lemak bebas dengan gliserol kembali terbentuk, sehingga menyebabkan nilai FFA menurun pada suhu ekstraksi yang lebih tinggi. Pecha et al. (2016) menyatakan bahwa reaksi hidrolisis ikatan ester pada trigliserida dan bersifat reversibel dalam kondisi asam dan netral. Asam lemak bebas minyak ikan layang hasil ekstraksi pada semua perlakuan suhu belum memenuhi persyaratan IFOS (2014) yaitu $\leq 1,5 \%$ (Table 2).

\section{Bilangan Peroksida (PV)}

Bilangan peroksida atau peroxide value (PV) adalah salah satu parameter yang dapat digunakan untuk mengukur tingkat kerusakan pada minyak. Senyawa ini terbentuk oleh reaksi oksidasi yang disebabkan oleh oksigen bebas yang berikatan dengan ikatan rangkap pada asam lemak tak jenuh dalam minyak (Kusnandar 2010). Reaksi oksidasi terdiri dari tiga tahapan yaitu inisiasi, propagasi, dan terminasi. Reaksi oksidasi primer pada lipid menghasilkan produk utama berupa hidroperoksida yang bersifat tidak stabil terhadap oksigen, sehingga mudah mengalami oksidasi sekunder yang menghasilkan senyawa turunan yang lebih stabil (Armstrong dan Browne 1994). Memon et al. (2010) melaporkan bahwa minyak ikan mengandung asam lemak tak jenuh ganda yang tinggi dan memiliki tingkat kestabilan yang rendah, sehingga mudah mengalami kerusakan akibat oksidasi.

Bilangan peroksida minyak ikan layang cenderung meningkat seiring dengan meningkatnya suhu ekstraksi. Hasil analisis sidik ragam (varian) menunjukkan bahwa perlakuan suhu ekstraksi berpengaruh nyata $(p \leq 0,05)$ terhadap PV minyak ikan layang. Uji lanjut Duncan menunjukkan bahwa PV pada suhu ekstraksi $40{ }^{\circ} \mathrm{C}$ berbeda nyata dengan suhu lainnya. Hasil ini sesuai dengan penelitian Suseno et al. (2014) yaitu PV minyak jeroan ikan tembang (S.gibbosa) hasil ekstraksi wet rendering cenderung meningkat seiring dengan meningkatnya suhu ekstraksi. Armstrong dan Browne (1994) menyatakan bahwa laju oksidasi asam lemak tak jenuh dapat dipengaruhi oleh suhu, sehingga semakin tinggi suhu maka PV akan semakin tinggi. Bilangan peroksida tertinggi terdapat pada suhu ekstraksi $60{ }^{\circ} \mathrm{C}$ sebesar $4,91 \mathrm{mEq} /$ kg (Table 2). Hasil ini lebih rendah dari PV minyak ikan layang hasil ekstraksi steam and press suhu $90{ }^{\circ} \mathrm{C}$ selama 15 menit yaitu sebesar $8,20 \mathrm{mEq} / \mathrm{kg}$ (Luthfiah et al. 2014). Bilangan peroksida minyak ikan layang hasil ekstraksi pada semua perlakuan suhu telah memenuhi persyaratan IFOS (2014) yaitu $\leq 5 \mathrm{mEq} / \mathrm{kg}$ (Table 2).

\section{Bilangan p-Anisidin (p-AV)}

Bilangan $p$-anisidin atau p-anisidine value (p-AV) dapat digunakan untuk memperkirakan adanya senyawa hasil dekomposisi hidroperoksida hasil oksidasi sekunder (Hogan et al. 2003). Proses oksidasi sekunder dari PV dapat terjadi selama periode waktu penyimpanan minyak (Guilln dan Cabo 2002). Bilangan $\mathrm{p}$-anisidin minyak ikan layang meningkat seiring dengan meningkatnya suhu ekstraksi. Hasil analisis sidik ragam (varian) menunjukkan bahwa perlakuan suhu ekstraksi berbeda nyata $(p \leq 0,05)$ terhadap p-AV minyak ikan layang. Uji lanjut Duncan menunjukkan bahwa p-AV pada setiap perlakuan suhu ekstraksi berbeda nyata. Penelitian Suseno et al. (2014) menunjukkan bahwa bilangan $\mathrm{p}-\mathrm{AV}$ minyak jeroan ikan tembang (S. gibbosa) hasil ekstraksi wet rendering cenderung meningkat seiring dengan meningkatnya suhu ekstraksi. Nilai bilangan p-AV minyak ikan layang tertinggi terdapat pada suhu ekstraksi $60{ }^{\circ} \mathrm{C}$ sebesar $6,69 \mathrm{mEq} /$ kg (Table 2). Hasil ini lebih rendah dari p-AV minyak ikan layang (Decapterus sp.) hasil ekstraksi steam and press suhu $90{ }^{\circ} \mathrm{C}$ selama 15 menit yaitu sebesar $8,56 \mathrm{mEq} / \mathrm{kg}$ (Luthfiah et al. 2014). Bilangan p-AV minyak ikan layang hasil ekstraksi pada semua perlakuan suhu telah memenuhi persyaratan IFOS (2014) yaitu $\leq 20 \mathrm{mEq} / \mathrm{kg}$ (Table 2).

\section{Total Oksidasi (TOTOX)}

Nilai total oksidasi atau total oxidation (TOTOX) merupakan indikasi nilai oksidasi secara keseluruhan pada minyak dengan batas maksimal yang dapat diterima dari hasil penjumlahan $\mathrm{PV}$ dan $\mathrm{p}-\mathrm{AV}$ 
(Waterhouse et al. 2011). Kualitas minyak ikan yang baik berdasarkan IFOS (2014) memiliki nilai TOTOX sebesar 19,5 mEq/kg. Nilai oksidasi minyak ikan layang meningkat seiring dengan meningkatnya suhu ekstraksi. Nilai TOTOX tertinggi terdapat pada perlakuan suhu ekstraksi $60{ }^{\circ} \mathrm{C}$ sebesar 16,5 $\mathrm{mEq} / \mathrm{kg}$ (Table 2). Hasil analisis sidik ragam (varian) menunjukkan bahwa perlakuan suhu ekstraksi berpengaruh nyata $(p \leq 0,05)$ terhadap TOTOX minyak ikan layang. Uji lanjut Duncan menunjukkan bahwa TOTOX pada setiap perlakuan suhu ekstraksi berbeda nyata. Hasil berbeda terdapat pada penelitian Suseno et al. (2014) bahwa perlakuan suhu ekstraksi wet rendering tidak berpengaruh nyata terhadap nilai TOTOX minyak jeroan ikan tembang yang dihasilkan. Rodríguez et al. (2012) menunjukkan darihasil penelitiannya bahwa degradasi asam lemak tak jenuh ganda (PUFA) oleh pro-oksidan seperti suhu, oksigen, logam, dan cahaya dapat meningkatkan nilai TOTOX pada minyak.Nilai TOTOX minyak hasil ekstraksi pada semua perlakuan suhu telah memenuhi persyaratan IFOS (2014) yaitu $\leq 26 \mathrm{mEq} / \mathrm{kg}$.

\section{KESIMPULAN}

Karakteristik mutu minyak ikan layang terbaik diperoleh dari ekstraksi perlakuan suhu $60{ }^{\circ} \mathrm{C}$ dengan nilai $\mathrm{PV}, \mathrm{p}-\mathrm{AV}$, dan TOTOX yang telah memenuhi persyaratan IFOS dengan rendemen sebesar $0,9 \pm 0,04 \%$.

\section{DAFTAR PUSTAKA}

Adeoti IA, Hawboldt K. 2014. A review of lipid extraction from fish processing byproduct for use as a biofuel. Journal of Biomass and Bioenergy. 63: 330-340.

Armstrong D, Browne R. 1994. The analysis of free radicals, lipid peroxides, antioxidant, enzymes, and compounds related to oxidative stress as applied to the clinical chemistry laboratory. Journal of Free Radicals Diagnostic Medicine. 366: 43-56.

[AOAC] Association of Official Analytical Chemist. 2005. Official Method of Analysis of the Association of Official Analytical of Chemist. Virginia (US): Published by The Association of Analytical Chemist, Inc.

[AOCS] American Oil Chemists' Society.
1997. Official method $\mathrm{cd} 8-53$ peroxide value, cd18-90 p-ansidine value, cg 3-91 recommended practices for assessing oil quality and stability In Official Methods and Recommended Practices of the American Oil Chemists' Society. Urbana (US): AOCS Pr.

[BSN] Badan Standardisasi Nasional. 2018. Penentuan kadar asam lemak bebas dengan metode titrasi alkalimetri. SNI 8392.1-1018. Jakarta (ID): Badan Standardisasi Nasional.

[BSN] Badan Standardisasi Nasional. 2018. Penentuan bilangan peroksida pada minyak ikan dengan metode titrasi iodometri.SNI 8392.2-1018. Jakarta (ID): Badan Standardisasi Nasional.

Carvajal AK, Slizyte R, Storro I, Aursand M. 2015 . Production of high quality fish oil by thermal treatment and enzymatic protein hydrolysis from fresh Norwegian spring spawning herring by-products. Journal of Aquatic Food Product Technology. 24(8): 807-823.

Castell JD, Sinnhuber RO, Lee DJ, Wales JH. 1972. Essential fatty acid in the diet of rainbow trout (Salmo gairdneri) : Physiological symptoms of EFA deficiency. Journal of Nutrition. 102: 8792.

Deslianti B, Kurnia A, Muskita WH. 2016. Studi penggunaan tepung ikan layang (Decapterus ruselli) dengan tepung ikan tongkol (Euthynnus afffinis) dalam pakan terhadap kecernaan juvenile udang vaname (Litopenaeus vannamei). Media Akuatika. 1(4): 261-269.

[DJPT] Direktorat Jendral Perikanan Tangkap. 2016. Statistik Perikanan Tangkap d Laut Menurut Wilayah Pengelolaan Perikanan (WPP) 2010-2015. Jakarta (ID): Kementrian Kelautan dan Perikanan Republik Indonesia.

Estiasih T. 2009. Minyak Ikan, Teknologi dan Penerapannya untuk Pangan dan Kesehatan. Yogyakarta(ID): Graha Ilmu.

Guilln MD, Cabo N. 2002. Fourier transform infrared spectra data versus peroxide and anisidin values to determine oxidative stability of edible oils. Journal of Food Chemistry. 77: 503-510. 
Hadinoto S, Kolanus JPM. 2017. Evaluasi nilai gizi dan mutu ikan layang (Decapterus sp) presto dengan penambahan asap cair dan ragi. Majalah BIAM. 13(01): 22-30

Hamka E, Rais M. 2016. Penentuan musim penangkapan ikan layang (Decapterus sp.) di Perairan Timur Sulawesi Tenggara. Journal of IPTEKS. 2(6): 1-9.

He K. 2009. Fish, long-chain omega-3 polyunsaturated fatty acids and prevention of cardiovascular disease-eat fish or take fish oil supplement. Journal of Progress in Cardiovascular Disease. 52: 95-144.

Hogan SA,O'riordan ED, O'sullivan. 2003. Microencapsulation and oxidative stability of spray-dried fish oil emulsions. Journal of Microencapsul. 20(5): 675-688.

[IFOS] International Fish Oil Standard. 2014. Fish Oil Purity Standars. [Diakses pada 10 Agustus 2019] Tersedia di :www. Omegavia.com/best.

Imbir E, Onibala H, Pongoh J. 2015. Studi pengeringan ikan layang (Decapterus sp) asin dengan penggunaan alat pengering surya. Jurnal Media Teknologi Hasil Perikanan. 3(1): 13-18.

[IUPAC] International Union on Pure an Apllied Chemistry. 1987. Standard methods for the analysis of oils arld fats and derivatives, 7 th ed. Paquot $\mathrm{C}$ dan Hautfenne A, editor. Oxford (GB): Blackwell Scientific.

Kamini, Suptijah P, Santoso J, Suseno SH. 2016. Ektraksi dry rendering dan karakterisasi minyak ikan dari lemak jeroan hasil samping pengolahan salai patin siam (Pangasius hypothalmus). Jurnal Pengolahan Hasil Perikanan Indonesia. 19(3): 196-205.

Ketaren S. 2012. Pengantar Teknologi Minyak dan Lemak Pangan. Jakarta (ID) : UI Press.

Kusnandar F. 2010. Kimia Pangan Komponen Makro. Jakarta (ID): Dian Rakyat Press.

Luthfiah, Genisa J, Metusalach, Abustam E, Sabahannur S, Ramadhan W. 2014. Analysis quality fish oil (Decapterus sp.) containing omega-3 using extraction method (steam and press) and (Bligh and Dyer). Journal of Advances in
Environmental Biology. 8(22): 923-929.

Memon NN, Talpur FN, Sherazi STH, Bhanger MI. 2010. Impact of refrigerated storage on quality of oil from freshwater Jarko (Wallago attu) fish. Pakistan Journal Analytical and Environmental Chemistry. 11(2): 37-43.

Metillo EB, Eya AAA. 2014. Fatty acid in six small pelagic fish species and their crustacean prey from the Mindanao Sea, Southern Philippines. Tropical Life Sciences Research Journal. 25(1):105-115.

Nurpratama D. 2019. Pengaruh Chilling terhadap profil asam lemak ikan layang (Decapterus ruselli). [Skripsi]. Bogor (ID): Institut Pertanian Bogor.

Pecha J, Sanek L,Furst T, Kolomaznik K. 2016. A kinetic study of the simultaneous methanolysis and hydrolysis of triglycerides. Chemistry Engineering Journal. 288: 680-688.

Pramestia SP, Riyanto B, Trilaksani W. 2015. Mikroenkapsulasi minyak ikan kaya asam lemak omega-3 sebagai bahan fortifikasi pada sup krim kepiting instan. Jurnal Pengolahan Hasil Perikanan Indonesia. 18(2): 162-176.

Richard D, Brien, O. 2008. Third Edition Fats and Oil. New York (US): CRC Press.

Rodríguez NR, Diego SM., Beltran S, Jaime I, Sanz MT, Rovira J. 2012. Supercritical fluid extraction of fish by-product: a comparison with other extraction methods. Jurnal of Food Engeenering. 109(2): 238-248.

Rozi A, Ukhty N, Khairi I, Irhamdika, Meulisa AI, Bija S. 2019. Karakterisasi asam lemak minyak hati cucut (Centrophorus sp.) yang diekstraksi dengan metode dry rendering. Jurnal Pengolahan Hasil Perikanan Indonesia. 22(3): 414-422.

Scrimgeour C. 2005. Bailey's Industrial Oil and Fat Products.Shahidi F, editor. Canada (CA): Wiley-Interscience.

Suseno SH, Syari C. Zakiyah ER. 2014. Low temperature and quality of oil from spotted sardinella (Amblygaster sirm) and goldstrip sardinella (Sardinella gibbosa). World Journal of Fish and Marine Sciences. 6(5): 435-440.

Suseno SH, Riskon AK, Jacoeb AM, Nurjanah, Supinah P. 2020. Ekstraksi dry rendering 
dan karakterisasi minyak ikan patin (Pangasius sp.) hasil samping industri filet di Lampung. Jurnal Pengolahan Hasil Perikanan Indonesia. 23(1): 38-46.

Wanasundara UN. 1996. Marine oil: Stabilization, structural characterization and omega-3 fatty acid concentration.
[Disertasi]. Ottawa (CA) : University of New Foundland.

Waterhouse DS, Zhou J, Meskelly GM, Wibisono R, Wadhawa SS. 2011. Stability of encapsulated olive oil in the presence of caffeic acid. Journal Food Chemistry. 126: 1049-1056. 